\title{
Ю.О. Пічугіна
}

Харківський національний університет міського господарства імені О.М. Бекетова, Украӥна

\section{БЛОКЧЕЙН: НОВІ ЕКОНОМІЧНІ ТА УПРАВЛІНСЬКІ РІШЕННЯ В АРТ-ІНДУСТРІї}

В статті актуалізовано значення блокчейну в економічних та управлінських прочесах на арт-ринку. 3'ясовано ключові інновачійні якості блокчейн-реєстру в арт-індустрії. Контекст дослідження звужений до цุифрового мистецтвва, в якому кінцевий художній продукт частіше за все повністю позбавлений будь-яких фізичних форм. Його реалізація відбувається виключно в иүифровому просторі, щзо в той же час вказує на дематеріалізацію изифрового мистецтва за його межами. Отже, переваги блокчейн-технологій в економіці мистецттва найкраще розкриваються саме тут, на ринку дематеріалізованих товарів $i$ гаманців. Основуючись на реальних прикладах (Бенксі “Morons (White)”, Майк Вінкельман “Everydays: The first 5000 Days”, CryptoKitties), визначено ефективність блокчейн-технологій в арт-індустрії. Розглянуто вплив блокчейну на зміни в організаційній роботі традиційних продавців мистецттва (аукціонних будинків, галерей, дилерів), а також окреслено нового суб'єкта товарно-грошових відносин на ринку мистецтва - арт маркетплейси.

Ключові слова: образотворче мистецтвво, арт-ринок, блокчейн, NFT, ициррове мистецтвво, циифрова економіка.

\section{Постановка проблеми}

Блокчейн, який ще кілька років тому вважався черговою розвагою 3 Кремнієвої долини, вже сьогодні по всьому світу визнається дієвим інструментом вдосконалення діяльності в багатьох сферах економіки, забезпечивши можливості реалізації того, що до цього моменту вважалось або неможливим, або мінімально ефективним. Так, артіндустрія однією з перших відреагувала на появу нової технології, знайшовши для нього місце майже в усіх процесах ринкової діяльності.

Отже, в контексті даної теми цікаво прослідити яким чином арт-ринок, решті в решт, завдяки технології блокчейну, набув чітких та прозорих механізмів для реалізації своїх функцій.

\section{Аналіз останніх досліджень та публікацій}

Наразі блокчейн став однією 3 найбільш обговорюваних тем у науковій спільноті $[1,11,12]$. Але питання реалізації можливостей блокчейну в арт-індустрії поки що недостатньо розкрито. Однією 3 найповніших робіт з цієї теми є публікація Мельник Ю.В. [2], в якій змістовно окреслено переваги блокчейн-технологій в менеджменті мистецтва, це: прозоре формування провенансу, тобто у блокчейнреєстр може заноситися підтверджена інформація про всю історію існування роботи - від моменту першого придбання до кожного перепродажу, участі у виставках, ярмарках, каталогах, публікаціях, приватних та публічних колекціях; «віртуальний нотаріат», що передбачає підтвердження рішень стосовно права власності та інших прав у режимі онлайн; «цифровий реєстратор» авторських прав дає змогу фіксувати в блокчейні час створення, авторські права та право власності митця на свою роботу; гарантія достовірності через «розумне маркування» та «синтетичну ДНК», тобто авторизовані художником після завершення твори мистецтва можуть відповідним чином маркуватися, а дані про це маркування записуватимуться у блокчейн і слідуватимуть за твором протягом усього часу існування; «розумні контракти» між продавцем i покупцем (отримання продавцем коштів лише після того, як покупець отримає придбаний твір завдяки автоматизації транзакції в блокчейн-системі) та «розумні контракти» інтегровані в аукціони (після завершення аукціонних торгів автоматично можуть вступати в дію кілька умов: списання коштів 3 покупця, нарахування комісійних аукціонному будинку та інших виплат) тощо [2, с. 52-53]. Деякі питання в цьому напрямі вирішувались також в наших попередніх працях $[8,9]$.

У вивченні даної теми безумовно важливими $є$ дослідження традиційних форм арт-ринку та механізмів арт-менеджменту. Це роботи українських дослідників Оленіної О.Ю. [3-5], Павліченко Н.В. [6, 7], Сухонос М.К. та Момот Д.Т. [10], а також великий пласт наукових напрацювань закордонних авторів.

Мета - визначити ефективність блокчейн- 
технологій відносно економічних та управлінських процесів в арт-індустрії, базуючись на реальних нещодавніх прикладах.

\section{Виклад основного матеріалу}

Ключовими інноваційними якостями блокчейнреєстру $\epsilon$ спосіб його зберігання - в різних, незалежних один від одного, місцях, а також вільний доступ до нього, що забезпечує абсолютну прозорість будь-яких операцій, записаних у реєстрі $[11,12]$. Здавалося, що може бути спільного між такою складною технологічною системою і мистецтвом, але, як вище зазначено, саме мистецтво одним 3 перших стало використовувати блокчейн на свою користь.

Насамперед, зауважимо, що особливого значення потенціал блокчейн-технологій набуває в цифровому мистецтві, в сфері якого раніше неможливо було створити дефіцит на твір, оскільки інтернет давав змогу нескінченно копіювати будьяке зображення миттєво і безкоштовно, що стало причиною багатьох суперечок $з$ приводу визначення авторства твору та його використання. Крім того, коли мова заходить про різні прояви цифрового мистецтва, слід звернути увагу на те, що кінцевий художній продукт частіше за все повністю позбавлений будь-яких фізичних форм. Його реалізація відбувається виключно в цифровому просторі, що в той же час вказує на дематеріалізацію цифрового мистецтва за його межами.

Наглядною демонстрацією до цього судження $є$ нещодавній приклад публічного знищення картини британського вуличного художника Бенксі "Morons (White)". У березні 2021 року блокчейн-компанія Injective Protocol вийшла у прямий ефip у Twitter, в ході якого представник компанії спалив сатиричну роботу Бенксі, що висміює колекціонерів, які витрачають купу грошей на художніх аукціонах. Але це не був акт вандалізму. Через кілька секунд після прямого включення робота Бенксі була конвертована y Non Fungible Token (NFT), який того ж дня був виставлений на аукціон і проданий в чотири рази дорожче від попередньої вартості. Так одна 3500 копій оригіналу припинила своє фізичне існування, перетворившись на виключно віртуальний актив у вигляді унікального цифрового коду, що ідентифікує роботу.

Детальніше зупинимось на NFT. Це унікальний не взаємозамінний запис у блокчейн-реєстрі, який неможливо підробити, розділити або підмінити. Така технологія створює ідеальні умови для сучасних форм мистецтва: це фіксація прав власності на будьякий унікальний цифровий об'єкт, при цьому можливості блокчейну не обмежуються сферою візуального мистецтва. Так, у березні 2021 року американський діджей 3LAU конвертував у NFT свій музичний альбом i продав його обмеженим накладом.

У лютому 2021 року на світовому художньому ринку сталася історична подія - на аукціоні Christie's вперше в історії традиційного арт-ринку було виставлено цифровий твір мистецтва. Цифровий колаж художника Майка Вінкельмана (Mike Winkelmann) "Everydays: The first 5000 Days" було продано за 69,3 млн \$ [13]. Покупець, як і в попередніх прикладах, отримав унікальний NFT iз зашифрованим підписом художника. Історія аукціонного будинку Christie's бере свій початок у 1766 році, це організація 3 віковими сталими традиціями роботи на ринку мистецтва, і сьогодні ми маємо нагоду спостерігати, як сучасний цифровий простір, створивши умови для розвитку нових художніх напрямів, одночасно пропонує нові рішення для повноцінного функціонування цих напрямів, навіть всередині таких канонічних структур, як аукціонні будинки.

Якщо про проведення подібних «транзакцій» стало широко відомо лише з поточного року, то про взаємопроникнення NFT і мистецтва ми знаємо ще 3 2017 року. Результатом такої співпраці стала перша блокчейн-гра CryptoKitties, яка побачила світ 28 листопада 2017 року завдяки розробникам канадської компанії AxiomZen. Суть гри полягає в придбанні, розведенні, колекціонуванні та продажі віртуальних кошенят, кожне 3 яких має власний унікальний 256-бітовий геном, що в потомстві дає 4 мільярди можливих генетичних варіацій, отже кожне народжене кошеня $€$ неповторним. При цьому, кожний 3 учасників гри отримує NFT, який підтверджує право власності на віртуальне кошеня.

Перші кріптокошенята були намальовані командою художників, які намагалися зробити продукт привабливим для широкої аудиторії, тому кошенята мають широкий спектр емоцій і характерів - від наймиліших (усміхнених i пухнастих) до фрикових (з божевільними очами та кликами). А цінність на подальші потомства, як і в образотворчому мистецтві, визначається їх рідкістю, соціальною актуальністю, особистими значеннями i естетичними вподобаннями. До речі, найдорожчий кріптокіт, проданий у 2021 році, коштував його новому власникові 1064022,75 дол. США. Це був Кітзасновник №40, один 3 сотні перших котів, запроваджених у грі, тобто з нульовим геном, а це найдорожчі [14].

В контексті цифрової економіки мистецтва важливо прослідити трансформації, які відбулись 3 продавцями творів образотворчого мистецтва, а саме аукціонними будинками, галереями, дилерами. Як видно 3 прикладу 3 продажом колажу Майка 
Вінкельмана "Everydays: The first 5000 Days", аукціонні будинки всупереч своїм сталим традиціям швидко адаптувались під новий формат товару. А галереї і дилери, в свою чергу, або ще не опанували новий сегмент ринку, або долучились до створення перших маркетплейсів цифрового мистецтва. Ці маркетиплейси, як правило, дозволяють будь-кому створювати, купувати або продавати NFT. Автор вільно може зайти на сайт або у додаток, зареєструватись, отримати сертифікат на свій цифровий контент (NFT) і продати або подарувати його за допомогою електронного гаманця, вбудованого в платформу або просто зберегти NFT в якості доказу своєї причетності до нього. Серед найвідоміших таких платформ: ArtOlin, Cargo, Crypto.com NFT, Art Blocks, Async Art, Foundation, SuperRare i багато інших.

На національному художньому ринку слід відзначити онлайн-платформу V-Art (https://vart.digital/), орієнтовану на популяризацію та просування саме цифрового мистецтва. Тут пропонується зареєструватися в якості художника, галериста, дилера, куратора або колекціонера для здійснення зрозумілої майбутньої взаємодії. Художник створює цифрові художні активи та демонструє їх у своєму акаунті, поціновувачі мистецтва знайомляться 3 їх творчістю, галереї i дилери створюють цифрові галереї або віртуальні зали для виставок і продажів, а інвестори отримують підтвердження ціни, історію продажів і гарантію на придбання [15]. Перевагами таких цифрових платформ є, по-перше, можливе охоплення всіх суб'єктів арт-ринку у звужених рамках добре структурованого простору платформи, а по-друге, це легкий та переважно безкоштовний доступ до такого плану ресурсів.

\section{Висновки}

Цифрове мистецтво у будь-яких свої проявах тривалий час залишалося поза ринковими відносинами, що зумовлювалось відсутністю механізмів регулювання його реалізації i підтвердження авторства, але 3 появою блокчейн-технологій починається новий виток в історії арт-індустрії. Блокчейн створив умови для прозорих та безпечних операцій на ринку традиційного мистецтва, і в той же час, шляхом конвертації творів цифрового мистецтва у NFT, зробив дематеріалізовану творчість предметом інвестиційної привабливості. Останнім часом ми можемо спостерігати появу все більшої кількості нових платформ на основі блокчейну, які спрямовані на вирішення старих завдань на «новому» арт-ринку.

Цікавим в якості перспективних досліджень в контексті цієї теми залишається питання про покупців арт-NFT. Власне, хто це і навіщо витрачати тисячі, десятки тисяч, а іноді й мільйони доларів на те, що не побачиш у себе на стіні в робочому кабінеті, не стане приводом для захоплення i заздрощів у гостей, не підкреслить вишуканого смаку його власника або не стане атрибутом успіху в очах оточуючих. Є припущення, що покупець мистецтва останніми роками змінився не менше ніж сам ринок. При цьому, не просто змінились вподобання у того самого покупця, а з'явився новий, раніше не зацікавлений в цьому.

\section{Література}

1. Демчишак Н.Б. Розвиток цифрової інфраструктури та блокчейн-технологій в Україні / Демчишак Н.Б., Радик В.В. // Інноваційна економіка. - 2020. - № 3-4. - С. 188-194. DOI: https://doi.org/10.37332/2309-1533.2020.3-4.27

2. Мельник Ю.В. Трансформація світового ринку творів мистецтва в умовах четвертої промислової революції / Мельник Ю.В. // Економіка і суспільство. - 2018. - Вип. 18. - C. 49-56. DOI: https://doi.org/10.32782/2524-0072/2018-18-8 3. Оленіна О.Ю. Особливості сучасного арт-ринку / О.Ю. Оленіна // Вісник Харківської державної академії дизайну і мистецтв, Сер.: Мистецтвознавство. Архітектура. - 2012. - № 6. - $\quad$ C. 93-97. URL: https://www.visnik.org/pdf/v2012-06-20-olenina.pdf

4. Оленіна О.Ю. Продавці мистецтва як комунікатори на художньому ринку / О.Ю. Оленіна // Культура України : зб. наук. пр. - 2013. - Вип. 40. - С. 167-176.

5. Оленіна О.Ю. Становлення та розвиток художніх ринків Європи в XVII-XIX ст. / О.Ю. Оленіна // Культура України : зб. наук. пр. - 2010. - Вип. 31. - С. 143-155.

6. Павліченко Н.В. Сучасний український арт-ринок: проблеми і рішення / Павліченко Н.В. // МАГІСТЕРІУМ. Cер. : Культурологія. - 2015. - Вип. 59. - С. 57-61. URL: http://ekmair.ukma.edu.ua/bitstream/handle/123456789/6910/ Pavlichenko_Suchasnyi_ukrainskyi_art_rynok.pdf

7. Павліченко Н.В. Художній ринок як культурологічний та економічний феномен / Павліченко Н.В. // МАГІСТЕРІУМ. Cер. : Культурологія. - 2017. - Вип. 68. - С. 72-75. URL: http://ekmair.ukma.edu.ua/bitstream/handle/123456789/12320/P avlichenko_Khudozhnii_rynok.pdf?sequence $=1$ \&isAllowed $=y$

8. Пічугіна Ю.О. Мережева творчість в контексті формування культурного капіталу в епоху 4.0 / Ю.О. Пічугіна // Комунальне господарство міст. Сер.: Економічні науки. - 2020. - Вип. 7(160). - C. 34-39. DOI: https://doi.org/10.33042/2522-1809-2020-7-160-34-39

9. Пічугіна Ю.О. Образотворче мистецтво на блокчейні / Ю.О. Пічугіна // Художня культура Греції та України в сучасному гуманітарному дискурсі : матер. міжнар. наук.практ. конф., 25-26 червня, 2019 р., м. Афіни, Греція. Харків : Мачулін, 2019. - C. 103-105. URL: https://eprints.kname.edu.ua/60061/1/\%D0\%9F\%D1\%96\%D1 $\% 87 \%$ D1\%83\%D0\%B3\%D1\%96\%D0\%BD\%D0\%B0.pdf

10. Сухонос М.К. Аналіз динаміки глобальних тенденцій на ринку арт-індустрії / М.К. Сухонос, Д.Т. Момот // Комунальне господарство міст. Сер.: Економічні науки. 2018. - Вип. 6(145). - С. 2-10. DOI: https://doi.org/10.33042/2522-1809-2018-6-145-2-10

11. Шольц Ю. Технология Blockchain. Принципы работы и перспективы применения / Юрген Шольц, Торстен Шелер, 
Ю. И. Соколов, В. С. Коцоева, А. А. Элькина // Финансы, налоги, учет. - 2017. - № 6. - С. 67-76.

12. Fanning K. Blockchain and its coming impact on financial services / Fanning K., Centers D.P. // J. Corp. Account. Finance. - 2016. - 27(5). - P. 53-57. DOI https://doi.org/10.1002/jcaf.22179

13. Beeple`s opus [Електронний ресурс]. - Режим доступу: https://www.christies.com/features/Monumental-collage-byBeeple-is-first-purely-digital-artwork-NFT-to-come-toauction-11510-7.aspx?sc_lang=en (дата звернення 19.10.2021)

14. Top 10 Most Expensive CryptoKitties Ever Sold In 2021 [Електронний pесурс]. - Режим доступу: https://www.nftsstreet.com/top-10-most-expensivecryptokitties-ever-sold-in-2021/ (дата звернення 15.11.2021) 15. We boost digital art market [Електронний pecypc]. Режим доступу: https://v-art.digital/ (дата звернення 19.10.2021)

\section{References}

1. Demchyshak N.B., Radyk V.V. (2020). The development of digital infrastructure and blockchain technologies in Ukraine. Innovative Economy, 3-4, 188-194. [in Ukrainian] DOI: https://doi.org/10.37332/2309-1533.2020.3-4.27

2. Melnyk, Y.V. (2018). Transformation of the global art market in the conditions of the fourth industrial revolution. Economy and Society, 18, 49-56. DOI: https://doi.org/10.32782/2524-0072/2018-18-8

3. Olenina, O.Yu. (2012). Features of the modern art market. Bulletin of Kharkiv State Academy of Design and Arts, 6, 9397. URL: https://www.visnik.org/pdf/v2012-06-20-olenina.pdf [in Ukrainian]

4. Olenina, O.Yu. (2013). Art sellers as communicators in the art market. Culture of Ukraine, 40, 167-176. [in Ukrainian] 5. Olenina, O.Yu. (2010). Formation and development of art markets in Europe in XVII-XIX centuries. Culture of Ukraine, 31, 143-155. [in Ukrainian]

6. Pavlichenko, N. (2015). Modern Ukrainian Art-market: Problems and Solutions. MAGISTERIUM, 59, 57-61. URL: http://ekmair.ukma.edu.ua/bitstream/handle/123456789/6910/Pa vlichenko_Suchasnyi_ukrainskyi_art_rynok.pdf [in Ukrainian]

7. Pavlichenko, N. (2017). Art Market as a Cultural and Economic Phenomenon. MAGISTERIUM, 68, 72-75. URL: http://ekmair.ukma.edu.ua/bitstream/handle/123456789/12320 Pavlichenko_Khudozhnii_rynok.pdf?sequence=1\&isAllowed =y [in Ukrainian]

8. Pichuhina Yu. (2020). Network creativity in the context of the formation of the cultural capital in the era of 4.0. Municipal economy of cities, 7(160), 34-39. [in Ukrainian] DOI: https://doi.org/10.33042/2522-1809-2020-7-160-34-39

9. Pichuhina Yu. (2019). Fine art on the blockchain. Proceedings of the International scientific-practical conference "Artistic culture of Greece and Ukraine in the modern humanitarian discourse”, 25-26 June 2019, Athens, Greece Kharkiv, Machulin, 103-105. [in Ukrainian] URL: https://eprints.kname.edu.ua/60061/1/\%D0\%9F\%D1\%96\%D1 \%87\%D1\%83\%D0\%B3\%D1\%96\%D0\%BD\%D0\%B0.pdf

10. Sukhonos, M., Momot, D. (2018). Dynamics analysis of global trends in the art industry market. Municipal Economy of Cities, 6(145), 2-10. DOI: https://doi.org/10.33042/25221809-2018-6-145-2-10 [in Ukrainian]

11. Scholz, J., Thorsten, Sh., Sokolov, Yu., Kotsoeva, V., Elkina, A. (2017). Blockchain technology. Principles of operation and prospects of application. Finance, taxes, accounting, 6, 67-76. [in Russian]

12. Fanning, K., Centers, D.P. (2016). Blockchain and its coming impact on financial services. J. Corp. Account. Finance, 27(5), 53-57. DOI: https://doi.org/10.1002/jcaf.22179 13. Beeple`s opus. (2021). URL: https://www.christies.com/features/Monumental-collage-by-

Beeple-is-first-purely-digital-artwork-NFT-to-come-toauction-11510-7.aspx?sc_lang=en Accessed 19 Oct 2021

14. Top 10 Most Expensive CryptoKitties Ever Sold In 2021. (2021). URL: https://www.nftsstreet.com/top-10-mostexpensive-cryptokitties-ever-sold-in-2021/ Accessed 15 Nov 2021

15. We boost digital art market. (2020). URL: https://Vart.digital/ Accessed 19 Oct 2021

Рецензент: д-р мистецтвознавства, проф., завідувач кафедри образотворчого мистецтва та дизайну О.Ю. Оленіна, Харківський національний університет міського господарства імені О.М. Бекетова, Україна.

Автор: ПІЧУГІНА Юлія Олександрівна кандидат наук із соціальних комунікацій, стариий викладач кафедри образотворчого мистеитва та дизайну

Харківський наџіональний університет міського господарства імені О.М. Бекетова

E-mail-Yuliia.Pichuhina@kname.edu.ua

ID ORCID: https://orcid.org/0000-0003-4019-5423

\section{BLOCKCHAIN: NEW ECONOMIC AND MANAGEMENT SOLUTIONS IN ART INDUSTRY}

Yu. Pichuhina

O.M. Beketov National University of Urban Economy in Kharkiv, Ukraine

The article actualizes the importance of the blockchain in economic and managerial processes in the art market. The purpose of the article is to determine the effectiveness of blockchain technologies in relation to economic and managerial processes in the art industry, based on real recent examples. The key innovative qualities of the blockchain register in the art industry have been clarified. The context of the study is narrowed to digital art, in which the final art product is often completely devoid of any physical forms. Its implementation takes place exclusively in the digital 
space, which at the same time indicates the dematerialization of digital art outside it. Therefore, the advantages of blockchain technology in art economic are best revealed here, in the market of dematerialized goods and wallets.

Recent examples of the conversion of fine art works to NFT (Banksy "Morons (White)", Mike Winkelman "Everydays: The first 5000 Days") are studied. They brought us closer to understanding the effectiveness of blockchain technology in the art industry. In the study, we turned to the origins of NFT, recalling the first blockchain game CryptoKitties (developed by AxiomZen), in the context of which all the conditions were created for the deployment of the digital art industry in its current form. The influence of blockchain on changes in the organizational work of traditional art sellers, including auction houses, galleries, dealers is considered. In 2021, Christie's auction was the first in the history of the traditional art market to put up for sale a lot of digital artwork, thus showing that the canonical subjects of the art market are ready for new challenges. The new subject of commodity-money relations in the modern art market - art marketplaces - is outlined. In the context of the national segment of the art market a multifunctional online platform V-Art is considered. It provides opportunities for all actors in the modern art market. The further perspectives of this research are outlined, which may be related to the analysis of the buyer of digital art works, who is it and why it does it, because the work of digital art has limited functionality compared to traditional physical works of art.

Keywords: fine arts, art market, blockchain, NFT, digital art, digital economy. 